\title{
PREDICTING NON-ADHERENCE TO MEDICATION REGIMENAMONG PATIENTS WITH HYPERTENSION: TAKING STEPS TOWARD ECOLOGICAL APPROACH
}

\author{
Olga Zamalijeva ${ }^{1}$, Roma Jusiené $\dot{1}^{1}$ Jolita Badariené $\dot{e}^{2,3}$ \\ ${ }^{I}$ Department of General Psychology, Faculty of Philosophy, Vilnius University, \\ ${ }^{2}$ Clinic of Cardiac and Vascular Diseases, Faculty of Medicine, Vilnius University, \\ ${ }^{3}$ Sub-department of Preventive Cardiology of the Department of Out-patient Cardiology, \\ Centre of Cardiology and Angiology, Vilnius University Hospital Santariskiu Clinics
}

Key words: non-adherence to medication regimen, social support, satisfaction with healthcare provider, perceived illness duration, hypertension.

\section{Summary}

Medication non-adherence among patients with hypertension is one of the main reasons for poor treatment efficacy, higher healthcare costs, increased patient morbidity and mortality. Despite numerous attempts to explain and improve adherence to long-term treatment regimen, the prevalence of non-adherence is still very common. Moreover, treatment adherence research rarely includes environmental variables as proposed by the ecological model. The aim of this study is to analyze the role of patient-level and micro-level variables in predicting medication non-adherence among patients with hypertension. Method. 101 hypertensive outpatients aged 33-93 $(\mathrm{M}=60.13$; $\mathrm{SD}=11.85)$ volunteered to participate in the study. A self-report questionnaire was constructed to assess subjects' adherence to medication regimen. Pivotal socioeconomic variables were recorded as well as treatment-related information, illnessrelated beliefs, perceived social support and satisfaction with the healthcare provider. Results show that perceived longer illness duration and higher satisfaction with the healthcare provider predict lower levels of intentional medication non-adherence. Younger age, higher intensity of side effects and lower levels of perceived social support predict higher unintentional medication non-adherence. Amount of prescribed medication has no direct effect on unintentional medication non-adherence, but is mediated through intensity of side effects. Results of this study emphasize the importance of environmental variables and recognition of various patterns of medication non-adherence, which provide additional understanding of the complexity of this health-related behavior.

\section{Introduction}

Hypertension can be considered one of the major challenges in the health care system worldwide. Rarely accompanied by any symptoms, this disease is attributed to approximately half of all strokes or ischemic heart disease [1] and is estimated to cause 12.8 percent of all deaths [2]. What is more, according to Lithuanian National health insurance fund, expenses on reimbursement of antihypertensive medication are the highest compared to other chronic diseases. Although researchers and practitioners agree that proper blood pressure control can prevent stroke and other cardiovascular events among patient with hypertension [3], poor adherence to antihypertensive therapy may result in 3 times higher odds of mortality [4] and persistence of antihypertensive treatment is important for clinical treatment results [5], still the lack of adherence to medication regimen in patients with hypertension is very common.

The level of non-adherence varies across different diseases. Usually non-adherence to treatment regimen is present among half of the patients treated for chronic diseases [6]. In case of hypertension, however, the prevalence of non-adherence reaches up to 80 percent [7]. Moreover, up to two thirds of patients with presumed resistant hypertension were non-adherent to treatment regimen [8]. Despite the prevalence of non-adherence and the role of adherence for the clinical outcomes, healthcare practitioners rarely consider this issue when working with patients and it rarely becomes the focus of research in Lithuania.

Having in mind that adherence to treatment regimen 
has enormous impact on patients' health, it is crucial to identify variables influencing medication adherence, since modifiable variables can be targeted for intervention [9]. There is a number of health behavior theories that contribute to understanding adherence behavior, however these theories are often supported by fragmented or contradictory evidence [10] and the effectiveness of commonly used interventions aiming to improve adherence is lacking [11]. Mentioned theories are predominantly focusing on the patient-related variables, but fail to encompass a broader approach and examine environmental factors proposed by the ecological model [12-13]. Of course, it is impossible to disregard the relevance of patient-related variables such as complexity of the regimen or side effects of medication $[6,14]$, various illness beliefs $[10,15]$ and self-efficacy [16-17]. Nevertheless, support from the immediate social environment and relationship with the healthcare professional, which are attributed to the micro-level [12], are also suggested to have a tangible impact on patients' disease management behavior $[6,18]$.

This is why the aim of this study is to analyze the role of patient-level and micro-level variables in predicting medication non-adherence among patients with hypertension.

\section{Material and method}

The study was carried out in a sample of 101 hypertensive outpatients ( $\mathrm{M}$ age $=60.13, \mathrm{SD}=11.85$, range: $33-93$ ) that volunteered to fill out the confidential questionnaire. Subjects were recruited using a non-probability convenien-

Table 1. Characteristics of the sample

\begin{tabular}{|c|c|c|c|}
\hline & & $\mathbf{N}$ & $\%$ \\
\hline \multirow{2}{*}{ Gender } & Male & 31 & 30.7 \\
\hline & Female & 70 & 69.3 \\
\hline \multirow{4}{*}{$\begin{array}{l}\text { Level } \\
\text { of edu- } \\
\text { cation }\end{array}$} & Primary or basic & 12 & 11.8 \\
\hline & Secondary & 35 & 34.7 \\
\hline & Higher non-university & 24 & 23.8 \\
\hline & Higher university & 30 & 29.7 \\
\hline \multirow{3}{*}{$\begin{array}{l}\text { Vocatio- } \\
\text { nal sta- } \\
\text { tus }\end{array}$} & Employed & 55 & 54.5 \\
\hline & Unemployed / retired & 45 & 44.6 \\
\hline & No responce & 1 & 1.0 \\
\hline \multirow{2}{*}{$\begin{array}{l}\text { Area of } \\
\text { residen- } \\
\text { ce }\end{array}$} & Urban & 47 & 46.5 \\
\hline & Rural & 54 & 53.5 \\
\hline
\end{tabular}

ce sampling technique (Table 1).

Non-adherence to medication regimen scale was constructed for the purpose of this research and measured 2 types of medication non-adherence: intentional and unintentional. Sample items include the following: "It happens that I forget to take my medication on time" and "It happens that I make a longer break from taking my medication." These were rated on a 4-point scale from never (1) to all the time (4). Higher scores indicate higher levels of non-adherence.

Confirmatory factor analysis (CFA) confirmed 2 factor model for the non-adherence to medication regimen scale $(\chi 2=25.746 ; \mathrm{df}=19 ; \mathrm{p}=0.137 ; \mathrm{CFI}=0.970 ; \mathrm{TLI}=$ 0.955 ; RMSEA $=0.060$ ). Both subscales have satisfactory reliability in the current sample, as Chronbach's internal consistency $\alpha$ was 0.67 and 0.82 .

Patient-level variables: Pivotal socioeconomic variables including age, gender, area of residence, level of education, vocational status and income were recorded. Subjects also reported specifics of their regimen as well as incidence and intensity of side effects. Psychological variables included self-efficacy and perceived illness duration.

Patients' self-efficacy was measured using General SelfEfficacy Scale [19]. Using CFA one factor model was confirmed $(\chi 2=41.687 ; \mathrm{df}=28 ; \mathrm{p}=0.046$; CFI $=0.975$; TLI $=0.959 ;$ RMSEA $=0.070)$. The scale also showed good reliability in the current sample, as Cronbach's internal consistency $\alpha$ was 0.91 .

Perceived illness duration was rated on a 10-point scale from 1 (very short) to 10 (for the rest of my life).

Micro-level variables included perceived social support as well as patients' satisfaction with the healthcare provider.

Perceived social support was specifically designed for this study and measured through 5-item scale, with the sample item, "My family members and / or friends fully support me." These were measured on a 5-point Likert-type scale ranging from not true at all (1) to very true (5). Scale has good psychometric characteristics. CFA confirmed one factor model $(\chi 2=2.882 ; \mathrm{df}=3 ; \mathrm{p}=0.410 ; \mathrm{CFI}=1.000$; $\mathrm{TLI}=1.000$; RMSEA $<0.000)$. The scale has satisfactory reliability in the current sample, as Chronbach's internal consistency $\alpha$ was 0.70 .

Satisfaction with the healthcare provider was specifically designed for this study and measured using 9 items, with the sample item, "The doctor devoted enough time to provide the best care possible." These were measured on a 5-point Likert-type scale ranging from completely disagree (1) to completely agree (5). CFA confirmed one factor mo$\operatorname{del}\left(\chi^{2}=37.024 ; \mathrm{df}=24 ; \mathrm{p}=0.414 ; \mathrm{CFI}=0.975 ; \mathrm{TLI}=\right.$ 
0.962 ; RMSEA $=0.074$ ) The scale also showed good reliability in the current sample, as Cronbach's internal consistency $\alpha$ was 0.90 .

\section{Data analyses}

Initial data analysis was conducted using SPSS 22 statistical package. Further analysis was conducted using structural equation modelling (SEM) with AMOS 22.

\section{Results}

Initial analysis showed that there no significant differences in intentional medication non-adherence between gender $($ male $\mathrm{M}(\mathrm{SD})=6.40(2.04)$; female $\mathrm{M}(\mathrm{SD})=5.95$ $(2.27) ; \mathrm{t}=0.960, \mathrm{df}=99, \mathrm{p}=0.340)$ and residential groups (urban $\mathrm{M}(\mathrm{SD})=5.74(2.26)$; rural $\mathrm{M}(\mathrm{SD})=6.39(2.13)$; $\mathrm{t}=-1.502, \mathrm{df}=99, \mathrm{p}=0.136)$. Also no differences were found between gender (male M (SD) $=6.84(1.80)$; female $\mathrm{M}(\mathrm{SD})=6.57(1.93) ; \mathrm{t}=0.643, \mathrm{df}=99, \mathrm{p}=0.522)$ and residential groups (urban $\mathrm{M}(\mathrm{SD})=6.36(1.90)$; rural $\mathrm{M}(\mathrm{SD})$ $=6.91(1.85) ; \mathrm{t}=-1.474, \mathrm{df}=99, \mathrm{p}=0.136)$ in unintentional medication non-adherence. Therefore these variables were not included in SEM analysis.

Figure 1 presents final structural model and standardized coefficients. The fit statistics of the model met the multiple criteria for adequately fitting model $\left(\chi^{2}=9.745\right.$; $\mathrm{df}=10 ; \mathrm{p}=0.634 ; \mathrm{CFI}=1.000 ; \mathrm{TLI}=1.000 ;$ RMSEA $<$ $0.001)$.

The final model indicates that perceived longer illness duration and higher satisfaction with the healthcare provider predict lower levels of intentional medication non-adherence. Younger age, higher intensity of side effects and lower levels of perceived social support predict higher unintentional medication non-adherence. Even though the amount of prescribed medication has no direct effect on unintentional medication non-adherence, it has indirect effect and is mediated through the intensity of side effects. General self-efficacy, educational level, financial and vocational status showed no significant impact on either type of medication non-adherence. Correlation between intentional and non-intentional non adherence is insignificant.

\section{Discussion}

Results of this study suggest that medication non-adherence should not be viewed as unidimensional construct, but rather as a construct including at least two types of non-adherence behavior, i.e. intentional and unintentional. This notion is supported not solely by the results of the factor analysis, but also by the fact that different types of medication non-adherence are predicted by different variables. Various researchers also recognize the importance of distinguishing different types of adherence [20-22]. De Geest and colleagues [8] proposed that comprehensive investigation of various medication-taking patterns is needed. Focusing research on different types of medication non-adherence will help understand the clinical significance of adherence and in addition provide with the evidence-based guidelines for developing targeted adherence promoting interventions.

The findings of this research show that intentional medication non-adherence can be predicted by patients' beliefs regarding illness duration. Even though hypertension is a long-term disease, not all patients see it as such. Since intentional medication non-adherence is an active decision-making process [20], patients' knowledge about the disease, as well as seeing the illness as more permanent, promotes a better understanding of the necessity of persistent antihypertensive treatment. Furthermore, results indicate that intentional medication non-adherence can

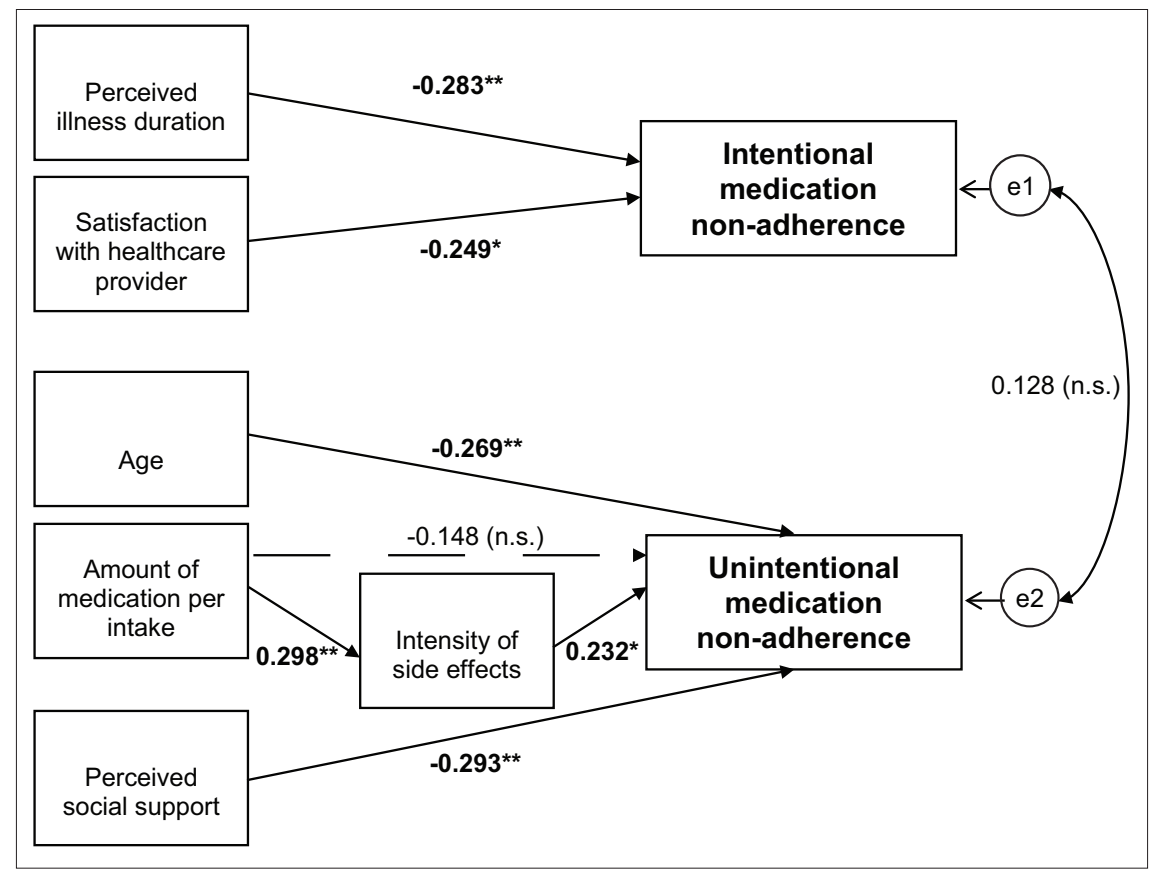

Figure 1. Final structural equation model for the predictive impact of personal- and microlevel variables on intentional and unintentional medication non-adherence $* p<0.05 ; * *<<0.01 ;$ n.s. - non-significant. 
be predicted by satisfaction with the healthcare provider. Considering that satisfaction with the healthcare provider is closely related to patient-provider communication [23], information-giving and quality of communication contribute to patients' understanding of illness and benefits of treatment [7], shaping more constructive attitudes and beliefs along with modifying the inaccurate ones. Therefore, improvement of communication between the patient and the healthcare provider through training physicians to communicate better might have a positive effect on intentional adherence behavior.

To the contrary, unintentional medication non-adherence is viewed as a more passive and irrational behavior [22], linked to forgetfulness [24], limited financial resources $[6,25]$, and increased by the presence of unpleasant side effects $[12,26]$ that make patients avoid medication. Since forgetfulness is often attributed to the older age, it is often believed that older patients would have poorer medication adherence due to possible limited cognitive resources or cognitive decline [27], however, results regarding age in the context of medication non-adherence are often contradictory $[6,22]$. Current study shows that older patients report lower levels of unintentional medication non-adherence. As suggested by other researchers, older adults have less busy everyday routines, which makes it easier to keep track of their medication schedules [27], moreover, taking medication is a more habitual task for older compared to younger adults [28]. Besides age, lower levels of unintentional medication non-adherence are predicted by higher levels of perceived social support. Social support is often associated with physical health outcomes, morbidity and mortality [29-31], and it is reasonable to expect that social support has significant ties with medication non-adherence. Assistance and encouragement of immediate social environment not only can alleviate emotional burden associated with the illness [18], but also can help the patient keep up with the medication schedule more accurately. Which is why patients' family members and close friends are a valuable resource that should be involved when necessary.

In addition, results of this research showed that relationship between the amount of medication per intake and unintentional medication non-adherence is mediated by the reported intensity of side effects. Complexity of medication regimen is repeatedly reported to have negative effect on medication adherence [6,32-33]. The higher the number of different drugs or number of daily dosing, the more difficult it becomes for the patient to follow the regimen. What is more, interventions aimed at simplification of medication regimen were found to be the most effective in improving adherence [11]. The findings of this research not only provide some insight on the link between regimen complexity and adherence, but also support the relevance of regimen simplifying interventions, e.g. reducing the number of pills when tackling the problem of unintentional medication non-adherence among patients with hypertension. However, monotherapy produces the desired effect only in limited number of patients, whereas majority of hypertensive patients require the combination of at least two drugs [34-35]. Thus, achieving balance between proper medication adherence and maintaining target blood pressure may seem challenging. On the other hand, when prescription of multiple agents is needed in order to achieve effective control of blood pressure, replacing multiplepill antihypertensive combinations with single-pill or otherwise called fixed-dose combinations provides treatment simplification and benefits medication adherence [36]. Moreover, drug combinations may also lessen the intensity of adverse side effects that are induced by high-dose monotherapy [35], while reduction of side effects is likely to promote better medication adherence.

Although self-efficacy is strongly associated with various health related behaviors [16-17], in this research self-efficacy was insignificant in predicting medication non-adherence. While it is suggested that self-efficacy plays the important role in the process of both initiating and maintaining of health behavior, it is also probable that, due to the novelty of the behavior, initiation requires believing in the capability to perform courses of action, whereas maintaining practice over a period of time may be more dependent on self-regulatory processes than it is on perceived self-efficacy [37]. Moreover, it can be assumed that the role of self-efficacy may vary depending on the type of behavior, since different behaviors require varying amount of planning and deliberation [38]. Compared to a variety of self-care activities, including weight control, low-salt diet, regular physical activity, limited alcohol and tobacco use, that are recommended in cases of hypertension, medication taking can be viewed as a routine behavior that does not require as much effort or competence for most patients. Therefore, self-efficacy in the context of maintaining proper medication adherence might only become important when obstacles arise.

In order to modify adherence behavior, practitioners developing interventions should take into account the type of medication non-adherence that they are aiming to improve. In addition, interventions should not be limited to patientlevel variables. Based on the results of this study, simplification of medication regimen through fixed-dose or singlepill combinations, addressing patient's concerns with side effects along with prompting the engagement of family and 
friends should be used for the subgroup of non-adherent patients who regularly forget to take their medication. On the contrary, aiming to decrease medication non-adherence among patients that deliberately alter the dosing or take "drug holidays" without consulting their physician, practitioners should try forming a collaborative partnership with the patient, which could facilitate identification and discussion of inaccurate beliefs regarding patients' illness or treatment.

Results of this study stress the importance of a broader perspective focusing on environmental micro-level variables in the context of adherence behavior, as satisfaction with the healthcare provider and perceived social support predict medication non-adherence. However, results of this research do not undermine the importance of patient-level variables such as health-related beliefs and attitudes. Further investigation of patients' beliefs, especially in relation with satisfaction with the health care provider, is needed. Also, future research should not be limited to medication adherence, but should include other self-care activities, since simultaneous analysis of various hypertension management behaviors may give a deeper understanding into the matter of adherence to long-term treatment regimen.

\section{Conclusions}

Intentional medication non-adherence can be predicted by perceived illness duration and the level of patients' satisfaction with the healthcare provider. Whereas unintentional medication non-adherence can be predicted by patients' age, intensity of medication side effects and perceived social support. No common predictors of intentional and unintentional medication non-adherence were identified, therefore, when aiming to improve medication adherence among patients with hypertension, distinguishing between intentional and unintentional medication non-adherence will allow more targeted interventions, which in turn may yield better results.

\section{Statement of conflict}

The authors state no conflict of interest.

\section{References}

1. Williams B. The year in hypertension. Journal of the American College of Cardiology 2010; 55(1): 65-73.

http://dx.doi.org/10.1016/j.jacc.2009.08.037

2. Alwan A, editor. Global status report on noncommunicable diseases 2010. Italy: World Health Organization 2011; 162.

3. Perreault S, Dragomir A, Roy L, White M, Blais L, Lalonde L, Bérard A. Adherence level of antihypertensive agents in coronary artery disease. British Journal of Clinical Pharmacology 2010; 69 (1): 74-84. http://dx.doi.org/10.1111/j.1365-2125.2009.03547.x

4. Herttua K, Tabák AG, Martikainen P, Vahtera J, Kivimäki M. Adherence to antihypertensive therapy prior to the first presentation of stroke in hypertensive adults: population-based study. European Heart Journal 2013; 34: 2933-2939.

http://dx.doi.org/10.1093/eurheartj/eht219

5. Veronesi M, Cicero AFG, Prandin MG, Dormi A, Cosentino E, Strocchi E, Borghi C. A prospective evaluation of persistence on antihypertensive treatment with different antihypertensive drugs in clinical practice. Vascular Health and Risk Management 2007; 3(6): 999-1005.

6. Sebaté E. editor. Adherence to Long-Term Therapies: Evidence for action. Geneva, Switzerland: World Health Organization $2003 ; 198$.

7. Osterberg L, Blaschke T. Adherence to medication. The New England Journal of Medicine 2005; 353:487-497.

http://dx.doi.org/10.1056/NEJMra050100

8. De Geest S, Ruppar T, Berben L, Schönfeld S, Hill MN. Medication non-adherence as a critical factor in the management of presumed resistant hypertension: a narrative review. EuroIntervention 2014; 9: 1102-1109. doi:10.4244/EIJV9I9A185

9. Morisky DE, Ang A, Krousel-Wood M, Ward HJ. Predictive validity of a medication adherence measure in an outpatient setting. The Juornal of Clinical Hypertension 2008; 10(5): 348-354.

http://dx.doi.org/10.1111/j.1751-7176.2008.07572.x

10. Munro S, Lewin S, Swart T, Volmink J. A review of health behavior theories: how useful are these for developing interventions to promote long term medication adherence for TB and HIV/AIDS? BMC Public Health 2007; 7 (104): 1-16.

http://dx.doi.org/10.1186/1471-2458-7-104

11. Van Dulmen S, Sluijs E, Van Dijk L, De Ridder D, Heerdink $\mathrm{R}$, Bensing J. Patient adherence to medical treatment: a review of reviews. BMC Health Services Research 2007; 7(55). http://dx.doi.org/10.1186/1472-6963-7-55

12. Berben L, Dobbels F, Engberg S, Hill MN, De Geest S. An Ecological Perspective on medication adherence. Western Journal of Nursing Research 2012; 34(5): 635-653.

http://dx.doi.org/10.1177/0193945911434518

13. AlGhurair SA, Hughes CA, Simpson SH, Guirguis LM. A systematic review of patient self-reported barriers of adherence to antihypertensive medications using the World Health Organization Multidimensional Adherence Model. The Journal of Clinical Hypertension 2012; 14(12): 877-886. http://dx.doi.org/10.1111/j.1751-7176.2012.00699.x

14. Grégoire JP, Moisan J, Guibert R, Ciampi A, Milot A, Côté I, Gaudet M. Tolerability of antihypertensive drugs in a community-based setting. Clinical Therapeutics 2001; 23(5): 715-726. http://dx.doi.org/10.1016/S0149-2918(01)80021-7

15. Chen SL, Tsai JC, Chou KR. Illness perceptions and adherence to therapeutic regimens among patients with hypertension: A structural modeling approach. International Journal of Nursing 
Studies 2011; 48:235-245.

http://dx.doi.org/10.1016/j.ijnurstu.2010.07.005

16. Bandura A. Health promotion by social cognitive means. Health Education and Behavior 2004; 31 (2): 143-164. http://dx.doi.org/10.1177/1090198104263660

17. Warren-Findlow J, Seymour RB, Bruner Huber LR. The Association Between Self-Efficacy and Hypertension SelfCare Activities Among African American Adults. Journal of Community Health 2012; 37(1): 15-24.

http://dx.doi.org/10.1007/s10900-011-9410-6

18. Yang YC, Boen C, Harris KM. Social relationships and hypertension in late life: evidence from a nationally representative longitudal study of older adults. Journal of Aging and Health 2014; 1-29.

http://dx.doi.org/10.1177/0898264314551172

19. Schwarzer R, Jerusalem M. Generalized Self-Efficacy scale. In: Weinman J, Wright S, Johnston M. Measures in health psychology: A user's portfolio. Causal and control beliefs. Windsor, UK: NFER-NELSON; 1995; 35-37.

20. Wroe AL. Intentional and Unintentional Nonadherence: A Study of Decision Making. Journal of Behavioral Medicine 2002; 25(4): 355-372.

http://dx.doi.org/10.1023/A:1015866415552

21. Clifford S, Barber N, Horne R. Understanding different beliefs held by adherers, unintentional nonadherers, and intentional nonadherers: Application of the Necessity-Concerns Framework. Journal of Psychosomatic Research 2008; 64: 41-46. http://dx.doi.org/10.1016/j.jpsychores.2007.05.004

22. Lehane E, McCarthy G. An examination of the intentional and unintentional aspects of medication non-adherence in patients diagnosed with hypertension. Juornal of Clinical Nursing 2007; 16: 698-706.

http://dx.doi.org/10.1111/j.1365-2702.2005.01538.x

23. Zolnierek, KBH, Dimatteo MR. Physician communication and patient adherence to treatment: A meta-analysis. Medical Care 2009; 47(8): 826-834.

http://dx.doi.org/10.1097/MLR.0b013e31819a5acc

24. Turner BJ, Hollenbeak C, Weiner MG, Have TT, Roberts C. Barriers to adherence and hypertension control in a racially diverse representative sample of elderly primary care patients. Pharmacoepidemiology and Drug Safety 2009; 18: 672-681. http://dx.doi.org/10.1002/pds.1766

25. Wu JR, Moser DK, Chung ML, Lennie TA. Predictors of medication adherence using a multidimensional adherence model in patients with heart failure. Journal of Cardiac Failure 2008; 14: 603-614.

http://dx.doi.org/10.1016/j.cardfail.2008.02.011

26. Quine L, Steadman L, Thompson S, Rutter DR. Adherence to anti-hypertensive medication: Proposing and testing a conceptual model. British Journal of Health Psychology 2012; 17 : 202-219. http://dx.doi.org/10.1111/j.2044-8287.2011.02034.x

27. Park DC, Hertzog C, Leventhal H, Morrell RW, Leventhal E, Birchmore D. et al. Medication adherence in rheumatoid arthritis patients: Older is wiser. Journal of American Geriatric Society 1999; 47:172-183.

http://dx.doi.org/10.1111/j.1532-5415.1999.tb04575.x

28. Brown SC, Park DC. Theoretical models of cognitive aging and implications for translational research in medicine. The Gerontologist 2003; 43(1):57-67.

http://dx.doi.org/10.1093/geront/43.suppl_1.57

29. Reblin M, Uchino BN. Social and emotional support and its implication for health. Current Opinion in Psychiatry 2008; 21(2): 201-205.

http://dx.doi.org/10.1097/YCO.0b013e3282f3ad89

30. Stephens C, Alpass F, Towers A, Stevenson B. The effects of types of social networks, perceived social support, and loneliness on the health of older people: accounting for the social context. Journal of Aging and Health. 2011; 1-25.

http://dx.doi.org/10.1177/0898264311400189

31. Sergin C, Domschke T. Social support, loneliness, recuperative processes, and their direct and indirect effects on health. Health Communication 2011; 26(3): 221-232. http://dx.doi.org/10.1080/10410236.2010.546771

32. Iskedjian M, Einarson TR, MacKeigan LD, Shear N, Addis A, Mittmann N, Ilersich AL: Relationship between daily dose frequency and adherence to antihypertensive pharmacotherapy: evidence from a meta-analysis. Clinical Therapeutics 2002; 24(2): 302-316.

http://dx.doi.org/10.1016/S0149-2918(02)85026-3

33. Ingersoll KS, Cohen J. The impact of medication regimen factors on adherence to chronic treatment: a review of literature. Journal of Behavioral Medicine 2008; 31: 213-224. http://dx.doi.org/10.1007/s10865-007-9147-y

34. Mancia G, Fagard R, Narkiewicz K, Redon J, Zanchetti A, Böhm M. et al. $2013 \mathrm{ESH} / \mathrm{ESC}$ Guidelines for the management of arterial hypertension. European Heart Journal. 2013; 34: 2159-2219. http://dx.doi.org/10.1093/eurheartj/eht151

35. Gradman AH, Basile JN, Carter BL, Barkis GL. Combination therapy in hypertension. Journal of the American Society of Hypertension 2010; 4(1): 42-50. http://dx.doi.org/10.1016/j.jash.2010.02.005

36. Gasgupta K, Quinn RR, Zarnke KB, Rabi DM, Ravani P, Daskalopoulou SS. et al. The 2014 Canadian Hypertension Education Program Recommendations for blood pressure measurement, diagnosis, assessment of risk, prevention, and treatment of hypertension. Canadian Journal of Cardiology 2014; 30: 485-501. http://dx.doi.org/10.1016/j.cjca.2014.02.002

37. Schwarzer R, Fuch R. Changing risk behaviors and adopting health behaviors: The role of self-efficacy beliefs. In: Bandura 
A, editor. Self-Efficacy in Changing Societies. Cambridge: Cambridge University Press 1995; 259-288.

http://dx.doi.org/10.1017/CBO9780511527692.011

38. Keatley D, Clarke DD, Hagger MS. The predictive validity of implicit measures of self-determined motivation across healthrelated behaviours. British Journal of Health Psychology. 2013; 18: 2-17.

http://dx.doi.org/10.1111/j.2044-8287.2011.02063.x

\section{HIPERTENZIJA SERGANČIŲJŲ MEDIKAMENTINIO GYDYMO NURODYMUৃ NESILAIKYMO PROGNOSTIN- IAI VEIKSNIAI: EKOLOGINIO POŽIŪRIO LINK \\ O. Zamalijeva, R. Jusienè, J. Badarienè}

Raktažodžiai: medikamentinio gydymo nurodymų nesilaikymas, socialinė parama, pasitenkinimas sveikatos priežiūros specialistu, suvokta ligos trukmè, hipertenzija

Santrauka

Medikamentinio gydymo nurodymų nesilaikymas hipertenzija sergančiujų grupejje yra viena pagrindinių prasto gydymo efektyvumo priežasčių ir siejamas su padidejusia neigalumo bei mirtingumo rizika. Nepaisant mokslininkų ir praktikų susidomèjimo šiuo sergančiujų elgesiu bei bandymų paaiškinti ir pagerinti medikamentinio gydymo nurodymų laikymąsi, su vaistų vartojimu susijusių gydymo rekomendacijų nevykdymas hipertenzija sergančiųjų grupejje yra vis dar labai dažnas. Be to, analizuodami medikamentinio gydymo nurodymų nesilaikymo prognozuojančius veiksnius, tyrejjai retai atsižvelgia ị socialinès aplinkos veiksnius, kurių svarbą pabrèžia ekologinis požiūris. Taigi, šio tyrimo tikslas - išanalizuoti sergančiojo lygmens ir mikrolygmens veiksnių reikš- mę hipertenzija sergančiųjų medikamentinio gydymo nurodymų nesilaikymui. Metodai. Tyrime sutiko dalyvauti 101 hipertenzija sergantis asmuo. Tiriamujų amžius buvo nuo 33 iki 93 metų (M $=60.13 ; \mathrm{SD}=11.85)$. Siekiant ịvertinti sergantiesiems būdingą medikamentinio gydymo nurodymų nesilaikymą, buvo parengtas klausimynas. Be to, papildomo klausimyno pagalba buvo surinkti duomenys apie pagrindinius sergančiųjų sociodemografinius rodiklius, medikamentinio gydymo ypatumus, sergančiojo įsitikinimus apie ligą, suvokiamą socialinę paramą ir pasitenkinimą savo sveikatos priežiūros specialistu. Rezultatai. Šio tyrimo rezultatai rodo, kad sergantieji, kurie savo ligą suvokia kaip ilgiau besitęsiančią ir yra labiau patenkinti savo sveikatos priežiūros specialistu, rečiau apgalvotai sumažina vartojamų vaistų dozę ar nutraukia vaistų vartojimą. Jaunesni, dažniau šalutinị vaistų poveikị patiriantys ir mažiau socialinės paramos gaunantys sergantieji dažniau pamiršta ar dèl kitų nenumatytų priežasčių neišgeria jiems paskirtų vaistų. Paskirtų vaistų kiekis neturi tiesioginio ryšio su netyčiniu vaistų nevartojimu, tačiau šis ryšys yra medijuojamas vaistų šalutinio poveikio dažnumo. Šio tyrimo rezultatai taip pat pabrèžia tyčinio ir netyčinio medikamentinio gydymo nurodymų nesilaikymo išskyrimo svarbą bei pademonstruoja aplinkos veiksnių vaidmenį, kas savo ruožtu suteikia papildomų žinių apie tokị sudètingą reiškinị kaip hipertenzija sergančiųjų gydymo nurodymų laikymasis.

Adresas susirašinėti: olga.zamalijeva@fsf.vu.lt

Gauta 2015-09-21 